DOI: 10.46340/eppd.2021.8.4.4

Denys Bobrovnyk, PhD in Economics

ORCID ID: https://orcid.org/0000-0002-1142-6926

Legislation Institute of the Verkhovna Rada of Ukraine

\title{
THE ROLE OF THE "HUMAN RIGHTS" CONCEPT \\ IN THE FORMATION OF INTERNATIONAL LEGAL \\ PERSONALITY OF THE TERRITORIAL HUMAN \\ COMMUNITY IN THE CONDITIONS \\ OF GLOBALIZATION
}

Денис Бобровник, к. е. н.

Інститут законодавства Верховної Ради України

\section{РОЛЬ КОНЦЕПТУ «ПРАВА ЛЮДИНИ» У ФОРМУВАННІ МІЖНАРОДНОЇ ПРАВОСУБ'СКТНОСТІ ТЕРИТОРІАЛЬНОЇ ЛЮДСЬКОЇ СПІЛЬНОТИ В УМОВАХ ГЛОБАЛІЗАЦІЇ}

The article is devoted to the study of the role and significance of the "human rights" concept in the formation of the international legal personality of the territorial human community in the context of globalization.

It is noted that a systematic analysis of the fundamental forms of globalization - economic, political, and its new form - legal globalization, shows that the phenomenology of "human rights" plays not only one of the most important roles in intensifying the rapprochement process on the international arena with metaintegration and paraintegration forms of cooperation, and integrative interaction between them - which is carried out on the basis of common political and legal values, among which human rights are central, as a fundamental hallmark of democratic and legal statehood - but is transformed into a fundamental feature of national constitutionalism, the basis of the constitutional system of an independent state (see Article 7 of the Constitution of Ukraine of 1996), a guideline for improving the activities of public authorities, increasing its effectiveness in the context of recognition, legalization, implementation, protection and guaranteeing rights, freedoms, and obligations of a human (individual) and citizen.

It is proved that in these processes the strategic role is played by territorial human communities territorial communities that exist and function in the conditions of local self-government at the local level of society in the ordinary state of everyday life, within which a person realizes his \her life cycle. Thus, the existential role and importance of communities that create appropriate organizational structures in local government - which are formed directly by their members, through the use of mechanisms of electoral democracy or democratic appointments (local governments - local councils, their executive committees, village, settlement, mayors, heads of united communities, elders, etc.) - are objectified and actualized by the fact that it is at the level of local self-government within the community man-resident and at the same time, its member realizes its constitutional and legal status - ie a set of rights freedoms and responsibilities established by the state and enshrined in its Basic Law (Constitution). Moreover, the purpose of such a constitutional and legal status is not so much a demonstration of the state's concern for its citizens, but the desire to provide people with more opportunities to address their existential interests, as the objective need to create an appropriate living environment for man, their groups and associations has its natural purpose - the continuation of the human race (reproduction) and the continued existence of human civilization.

It is pointed out that the understanding and awareness of these processes from the point of view of globalization can be described as solving the problems of global development of human civilization and fulfilling the natural purpose of man, which can be determined by "through" 
understanding of local, national, universal-global levels of society, their functional-logical interaction and the corresponding managerial and normative (local, national, international legal law-making and rule-making) activity, which explains, substantiates, determines, activates, actualizes and stimulates the appearance of such interaction.

It is argued that understanding the role and significance of the concept of "human rights" in the formation of international legal personality of the territorial human community in the context of globalization is important in the context of forming not only political meanings but also relevant actions-functions of individual states and their international community, including law-making and rule-making of different levels (local, national, international law) on the formation of an appropriate organizational, organizational and legal framework for the processes of formation of international legal personality of the community and especially its normative component.

It is concluded that the awareness and implementation of trends in the formation of international legal personality of the community in the context of globalization lie according to the author's three areas: in the field of globalization of human rights; in the field of formation of international legal standards, including relevant standards in the field of human rights and in the field of local self-government; in the field of formation and implementation of methodological and technological guidelines of global constitutionalism - will not only contribute to this strategic doctrinal-theoretical and at the same time praxeological-functional nature, but also intensify the processes of formation, and strengthening of globalist community potential.

Keywords: local self-government, territorial community, communicative interaction, concept «human right», interests of man and his associations.

Постановка проблеми. Системний аналіз основоположних форм глобалізації- економічної, політичної, а також ії нової форми - правової глобалізації, свідчить про те, що феноменологія «прав людини» відіграє не лише одну з найважливіших ролей в інтенсифікації процесів зближення держав на міжнародній арені через використання єдиних форм співробітництва в межах метаінтеграційної, параінтеграційної, а також інтеграційної взаємодії між ними, що здійснюється на основі єдиних політикоправових цінностей, серед яких права людини займають центральне місце, як основоположна ідентифікаційна ознака демократичної та правової державності, - а й трансформується в основоположну ознаку національного конституціоналізму, основу конституційного устрою незалежної держави (див. ст. 7 Конституції України 1996 року $^{1}$ ), орієнтир для вдосконалення діяльності органів публічної влади, підвищення іiі ефективності в контекстуалізації визнання, легалізації, реалізації, захисту, охорони, гарантуванню прав, свобод і обов'язків людини (особистості) і громадянина.

В зазначених процесах стратегічну роль відіграють територіальні людські спільноти територіальні громади (далі - ТГ), що існують та функціонують в умовах місцевого самоврядування (далі - MCB) на локальному рівні соціуму в умовах ординарного стану повсякденності, в межах яких людина реалізує свій життєвий цикл.

Отже, екзистенційна роль і значення ТГ, що в умовах МСВ створюють відповідні організаційні структури, які формуються безпосередньо їх жителями-членами, через застосування механізмів виборчої демократії або демократичних призначень (органи місцевого самоврядування - місцеві ради, їх виконавчі комітети, сільські, селищні, міські голови, голови об'єднаних ТГ, старости тощо) (далі - ОМСВ), об'єктивуються і актуалізуються тим, що саме на рівні МСВ в межах ТГ людинажитель і одночасно член ТГ реалізовує свій конституційно-правовий статус, тобто сукупність прав, свобод і обов'язків, встановлених державою і закріплених в їі Основному Законі (Конституції). Причому, метою реалізації такого конституційно-правового статусу виступає не стільки демонстрація відповідної турботи держави про своїх громадян, бажання надати людині більше можливостей для вирішення своїх екзистенційних інтересів, скільки об’єктивна необхідність створення відповідного життєвого середовища для людини, іiї груп і асоціацій з метою виконання телеологічних пріоритетів іiї природного призначення - продовження людського роду (репродукція) та подальшого існування людської цивілізації.

Отже, наведена система відносин виступає: а) не лиеш найважливішою основою демократичної правової державності (стратегічний критерій - авт.); до того ж б) вона володіє універсальним

\footnotetext{
${ }^{1}$ Конституиія Украӥни, 1996 (Верховна Рада України). Відомості Верховної Ради України, 30, 141.
} 
значенням для існування і функціонування всіх демократичних держав сучасності (універсальний критерій - авт.); в) складаючи відповідні управлінсько-статусні стратагеми, парадигми, алгоритми формування, функціонування і реалізації публічної влади (стратегічно-владний критерій - авт.), що, з одного боку, органічно поєднують настанови позитивного і природного, публічного і приватного права (стратегічно-дихотомічний критерій - авт.); а з іншого - спираються на політичну волю народу та здійснюються з метою реалізації системного комплексу колективних, групових та індивідуальних інтересів широких верств населення (стратегічно-біхевіористичний критерій - авт.). Одночасно наведена система складає систему координат в якій вирішуються глобальні завдання людської цивілізації: а) здійснення життєвого циклу людини в ТГ; б) реалізація репродуктивної функції людини; в) продовження іiі роду; г) подальший розвиток людської цивілізації (екзистенційноцивілізаційний критерій. - авт.), - а це, своєю чергою, може бути охарактеризовано вже під кутом зору глобалізації, як вирішення задач глобального розвитку людської цивілізації та виконання природного призначення людини, що може бути визначено за допомогою «наскрізного» розуміння локального, загальнодержавного, універсально-глобального рівнів соціуму у їх функціональнологічній взаємодії та відповідної управлінської та нормативної (локальне, загальнодержавне, міжнародно-правове нормопроєктування та нормотворчість /у підсумку, нормотворення/) діяльності (глобально-управлінський критерій - авт.), що пояснює, обгрунтовує, детермінує, активізує, актуалізує та стимулює появу такої взаємодії.

Звідси, виникаюча в межах ТГ та в умовах МСВ бінарність завдань локально-державного і глобального розвитку дозволяє стверджувати не лише про реальну життєздатність, а й про позитивну стереотипність такої побудови локально-державного, і одночасно, універсально-глобального соціуму, що в умовах глобалізації набуває особливого універсально-застосовного значення та трансформації рольових позицій традиційних суб'єктів національного конституційного права. Отже, ТГ як основному і первинному суб'єкту МСВ надаються відповідні риси глобалізованого суб'єкта-актора, що достатньо чітко, однозначно і якісно відображають, формують, прогнозують в особі ТГ сучасні і перспективні функціонально-діяльнісні конотації та наративи людської цивілізації загалом.

Аналіз останніх досліджень та публікацій. Теоретичні основи проблематики прав людини, починаючи від іiі природних прав, знаходили відображення у наукових доробках Т. Аквінського, Сократа, Платона, Аристотеля, Цицерона, Г. Гроція, Т. Гоббса, Дж. Локка, Ш.-Л. Монтеск'є та інших мислителів. Наведеній проблематиці були присвячені наукові публікації зарубіжних дослідників, таких як: Т. Аллан, А. Амірханов, Р. Барнет, Л. Батієв, Г. Бернацький, Є. Верховодов, М. Вітрук, Ю. Габермас, Р. Дворкін, О. Лукашова, Дж. Раз, С. Толлефсен, Л. Фулер, Г. Гарт, Л. Штраус.

Важливою в профільному контексті $є$ наукова спадщина українських дослідників XVI XX століть та сучасних авторів, з-поміж яких виокремлюються роботи Ю. Барабаша, Г. Вдовіної, С. Головатого, Д. Гудими, М. Драгоманова, А. Зайця, О. Зайчука, Б. Кістяківського, О. Кістяківського, Т. Дідича, С. Дністрянського, М. Козюбри, О. Копиленка, В. Корецького, О. Костенка, В. Культенко, В. Лемака, П. Лодія, Ю. Оборотова, О. Олійник, М. Орзіха, С. Оріховського, М. Палієнка, Л. Петражицького, В. Погорілка, О. Петришина, П. Рабіновича, В. Речицького, В. Скоморовського, В. Сокуренка, Ю. Тодики, І. Франка, А. Француза, Т. Француз-Яковець, П. Юркевича та інших.

Суттєвий внесок у дослідження прав людини в сфері місцевого самоврядування внесли наукові праці представників вітчизняної школи теорії права, конституційного і муніципального права, таких як: М. Баймуратов, О. Батанов, О. Боярський, Є. Васильєв, О. Васильченко, Р. Войтович, Б. Кофман, О. Кравець, О. Лотюк, О. Марцеляк, В. Могілевський, О. Приєшкіна та ін. Саме у їх дослідженнях розглядались та аналізувались проблеми вдосконалення системи державного і глобального управління шляхом здійснення конституційної, а також адміністративної та муніципальної реформ, що є складовими частинами реформи конституційної, при цьому головна увага приділялась інституційним та організаційно-правовим засадам цього процесу, серед останніх були проблеми формування «людини муніципальної», взаємодії «людини глобальної» і глобального суспільства, включаючи і проблематику глобалістського потенціалу МСВ і ТГ.

Водночас, констатуючи доволі значний обсяг наукових публікацій у царині прав людини та конституціоналізму, наявною $є$ недостатня опрацьованість питань ролі і впливу феноменології прав людини у формуванні міжнародної правосуб'єктності територіальної людської спільноти в умовах глобалізації.

Тому, метою даної статті виступає дослідження ролі концепту «права людини» у формуванні міжнародної правосуб’єктності територіальної людської спільноти в умовах глобалізації. 
Виклад основного матеріалу. У своєму семантичному розумінні права людини треба розуміти, як комплекс свобод і юридичних можливостей, обумовлених існуванням людини в суспільстві ${ }^{1}$. Отже, насамперед, права людини - це органічний сплав іiі свобод та юридичних можливостей здійснювати свою поведінку з метою реалізації (досягнення) таких свобод, самостійно визначаючи час, місце, форму, порядок та інші настанови такої поведінки. Важливою ідентифікаційною ознакою прав людини, що має основоположне значення для дослідження, що проводиться, $є$ те, що права людини фактично обгрунтовані, обумовлені та детерміновані, стимульовані та об'єктивовані існуванням людини в суспільстві. Враховуючи той факт, що людина конкретно здійснює свій життєвий цикл в межах локального соціуму, що уособлює територіальна людська спільнота (ТГ), саме вона виступає природним простором виникнення, формування, прояву, існування та сферою гарантування, охорони, захисту прав людини. Отже, саме тут: а) виникають стратегічні зв'язки горизонтально-вертикального характеру між ТГ та людиною, iї групами і асоціаціями, що сприяють: б) реалізації екзистенційних настанов людини - іiі інтенцій, устремлінь, потреб, інтересів, в) формуванню атитюдів (поведінкових настанов), що формуються в межах ТГ, та різнорівневих габітусів (досвіду людини в реалізації різних форм життєдіяльності через соціальну практику), що обгрунтовано настановами іiі соціалізації.

Звідси, наявність правових настанов, що апріорі виникають в ТГ є природно обгрунтованим, соціально детермінованим та функціонально доцільним, бо саме право виступає мірою свободи і зміст його міститься в тому, щоб узгодити свободу окремої людини зі свободою інших членів суспільства, дотримуючись принципу рівності, і створюючи систему комунікативної взаємодії в межах ТГ за допомогою МCB, що має за мету створення соціального безконфліктного простору, що базується на співробітництві, взаємній підтримці та взаємодопомозі. Саме тому право одночасно виступає як засобом забезпечення свободи, так і істотним засобом обмеження неузгоджених з суспільними потребами і уявленнями людей про добро і справедливість рівня свободи й обсягу влади. Встановлювані заборони й обмеження повинні бути доцільними з погляду гарантій свободи, а отже, $\mathrm{i}$ справедливими ${ }^{2}$.

Водночас, права людини мають природну сутність і $є$ невід'ємними від індивіда, вони з одного боку, - інституційно-релятивістського, є прив'язаними до локального рівня соціуму, ТГ та сфери МСВ, а також до держави (тобто, мають суто локально-державний характер), а з іншого - філософськогносеологічного, є позатериторіальними і позанаціональними, існують незалежно від закріплення в законодавчих актах держави, є об'єктом міжнародно-правового регулювання та захисту ${ }^{3}$, що фактично і детермінує їх глобалізаційну сутність та формує відповідні глобалізаційні риси.

Отже, ідея невідчужуваності прав людини, якими вона наділена від народження і яких не може бути позбавлена при будь-яких випадках, поряд з міркуваннями про рівність людей - стали тим внеском прибічників ідей та ідеалів природного права, котрими вони збагатили гасла соціальних трансформацій державно обумовленого соціуму - буржуазно-демократичних революцій і війн за незалежність у Європі та Північній Америці. Здійснюючи детальний аналіз ідеї невідчужуваності прав людини, вітчизняна дослідниця О. В. Пушкіна, абсолютно справедливо наголошує, що, поперше, поза науково-теоретичним аналізом цієї ідеї будь-яка реконструкція системи прав людини буде неповною та незавершеною. По-друге, цікавою $є$ теза вченого про необхідність уточнення змісту таких понять, як «невідчужувані» та «невід'ємні» права людини. Йдеться про те, що поняттям невідчужуваності описується сфера відносин між державою та людиною, коли на державу покладаються певні обмеження щодо ії дій у приватній сфері. На відміну від цього, продовжує О. В. Пушкіна, термін «невід'ємність» відсилає до природи прав людини, адже право є невід'ємним не тому, що його не може забрати держава, а тому, що воно вкорінене в самій людській природі ${ }^{4}$. Таке розуміння невід'ємності прав людини володіє великим методологічним та онтологічногносеологічним потенціалом, бо воно: а) підтверджує особливу i надважливу генетичну i функціональну роль територіальної людської спільноти (ТГ) у виникненні, формуванні, функціонуванні і реалізації концепту «права людини» в межах локального соціуму; б) підкреслює

\footnotetext{
${ }^{1}$ Wikipedia (2021). Права людини. < https://uk.wikipedia.org/wiki/Права_людини> (2021, липень, 28).

2 Тертишник, В. М. (2009). Верховенство права та забезпечення встановлення істини в кримінальному процесі Украӥни. Дніпропетровськ: ДДУВС; Ліра ЛТД, 52.

${ }^{3}$ Корельский, В.М., Перевалова, В.Д. (2002). Теория государства и права. Москва: НОРМА, 540.

${ }^{4}$ Пушкіна, О. В. (2006). Система прав і свобод людини та громадянина в Україні: теоретичні і практичні аспекти забезпечення. Київ: Логос, 35.
} 
згоду держави та їі публічної влади на здійснення таких процесів, бо саме ТГ виступає тим природним колективом в якому людина здійснює свій життєвий цикл та під впливом якого вона формується і соціалізується; в) акцентує увагу на тому, що в основі правосуб'єктності ТГ лежить їі визнання з боку людини, ії груп та асоціацій як єдиного соціально-структурованого простору в якому людина може продукувати і реалізувати свої екзистенційні настанови; ба більше, г) враховуючи особливий вплив ТГ на глобальні питання існування людської цивілізації (простір для оптимального здійснення життєвого циклу людини, простір для оптимального здійснення репродуктивної функції, простір для подальшого оптимального існування людської цивілізації тощо) саме тут територіальна людська спільнота в умовах глобалізації набуває свою міжнародну правосуб'єктність через набуття глобалізованої характерології.

Треба враховувати, що права людини досить часто не розрізняють та плутають з правами громадянина та правами фізичної особи. На нашу думку, це пов'язано з великим обсягом метаюридичних та параюридичних явищ, що спочатку супроводжують в історичній ретроспективі стохастичні процеси формування та розвитку нормативного обгрунтування прав людини в умовах державності, що формується, їх наступної легалізації в державі і соціумі, а потім супроводжують і забезпечують процеси їх легітимації, розвитку, вдосконалення, трансформації тощо, пристосовуючись до різних рольових позицій людини в соціумі та ії різних правових станів в державі.

Системний аналіз історико-ретроспективного ракурсу еволюції концепту «права людини» свідчить про те, що профільна феноменологія виступає центральною ідеєю в розвитку держави і соціуму, яка фактично спирається та базується, а також продукується і реалізується існуванням людської територіальної спільноти, де саме і проходить життєвий цикл конкретної людини. Саме на рівні такої спільноти (ТГ) фактично виникає об'єктивізація необхідності та суспільно-психологічні детермінанти, що стимулюють інституції публічної влади до розуміння і наступного формулювання відповідних соціальних можливостей, що надаються людині для реалізації ії екзистенційних інтересів в межах локального соціуму в умовах МСВ та в ординарному стані повсякденності через можливість реалізації устояних i, перевірених на практиці на предмет їх ефективності, форм життєдіяльності, застосування яких може призвести до відповідного позитивного соціального результату.

Отже, можна стверджувати, що, по-перше, феноменологія прав людини скерована на формування нових демократичних стандартів поведінки публічної влади та членів локального соціуму в межах ТГ. По-друге, така феноменологія хоча і $€$ історично мінливою категорію, однак вона розвивається і еволюціонує разом із суспільством і державою, враховуючи їх ретроспективний та перспективний розвиток та трансформацію в бік модернізації або стагнації - тобто, вона володіє суттєвими динамічними характеристиками та могутнім соціально-правовим потенціалом, що можуть здійснювати суттєвий вплив на державу і соціум. По-третє, кожному щаблеві історичного розвитку феноменології прав і свобод притаманна юридична концепція людини як суб'єкта права та відповідні уявлення про її права й обов'язки, свободи і несвободи. По-четверте, феноменологія прав і свобод людини та ії практичне втілення в конкретний системний комплекс іiї прав і свобод, - це природне, невід'ємне надбання, насамперед, людини і локального соціуму у перманентній боротьбі з державним етатизмом та авторитарними тенденціями публічної влади. Отже, по-п'яте, феноменологія прав людини, яка під впливом суспільної думки трансформується в концепт «права людини», а за допомогою права стає відповідною системою нормативних координат в формуванні, розвитку та вдосконаленні законодавства держави, причому на вищому, - конституційно-правовому рівні, а звідси, - однозначно стає конституційною цінністю людини, соціуму і держави.

У цьому контексті представляє методологічне значення доктринальна позиція вітчизняної дослідниці С. В. Бобровник, яка слушно зазначає, що процес суспільної діяльності людини значною мірою залежить від обсягу прав і свобод, які визначають іiі соціальні можливості, характер життєдіяльності, систему зв'язків людей у суспільстві. Тому проблема прав людини завжди була предметом політичної боротьби за володіння цими правами, розширення їх сфери та визначення становища людини в суспільстві. Права та свободи людини - це складне, багатоаспектне явище, пов'язане з генезою юридичних норм, які регламентують ці права та свободи. Становлення та розвиток прав і свобод людини має тривалу історію та супроводжується боротьбою доктрин i традицій, характерних для тієї чи іншої країни ${ }^{1}$.

\footnotetext{
1 Зайчук, О. В., Оніщенко, Н. М. (ред.) (2008). Теорія держави і права. Київ: Юрінком Інтер, 85; Оніщенко, Н. М., Зайчук, О. В. (ред.) (2007). Проблеми реалізації прав і свобод людини та громадянина в Україні. Київ: Юридична думка, 51.
} 
Треба зазначити, що системний аналіз, застосований до кожного 3 наведених положень доктринальної позиції, не тільки підкреслює наведені вище аргументи та висновки, він досить яскраво підкреслює особливу, первинну і природну роль ТГ у формуванні, розвитку та практичному застосуванні досліджуваного концепту «права людини», що характеризується екзистенційним значенням (саме вони визначають ऑї соціальні можливості, характер життєдіяльності), комунікативною основою (саме вони формують систему зв'язків людей у суспільстві); фундаментальним характером (проблема прав людини завжди була предметом політичної боротьби за володіння цими правами, розширення їх сфери та визначення становища людини в суспільстві); нормативною змістовністю (права та свободи людини - це складне, багатоаспектне явище, пов'язане 3 генезою юридичних норм, які регламентують ці права та свободи); безпековою сутністю (права та свободи людини фактично створюють можливості та гарантії для її безпеки в соціумі в умовах його державно-публічної та самоврядно-публічної організації); суттєвою історичною ретроспективою (становлення та розвиток прав і свобод людини має тривалу історію); відповідною краӥновою індивідуалізацією та особливостями (становлення та розвиток прав і свобод людини супроводжується боротьбою доктрин і традицій, характерних для тієї чи іншої країни); обтрунтованою глобалістською завантаженістю і наповненістю (права людини в контексті завдань продовження людської популяції та виживання людської цивілізації).

Наведені характерологічні риси концепту «права людини» фактично складають підгрунтя для формування внутрішньодержавної та міжнародної правосуб'єктності (далі- МПС) ТГ в умовах глобалізованого світу. Причому, якщо внутрішньодержавна правосуб'єктність ТГ повинна знайти своє належне і адекватне відображення і закріплення у конституційному та чинному законодавстві держави, то проблематика формування iї міжнародної правосуб'єктності лежить у площині здійснення колективних зусиль держав-членів міжнародної спільноти з активізації цілеспрямованих процесів міжнародного договірного нормотворення, тобто, через здійснення міжнародної нормопроєктної діяльності та міжнародної нормотворчості в межах міжнародного договірного права.

Одночасно, можна констатувати, що наведені тенденції в сфері формування МПС ТГ в умовах глобалізації можуть бути реалізованими за трьома напрямками:

1) у сфері глобалізації прав людини;

2) у сфері формування міжнародних правових стандартів, включаючи відповідні стандарти в сфері прав людини та в сфері МСВ;

3) у сфері формування та реалізації методологічних та технологічних настанов глобального конституціоналізму, що виступає мегатрендом сучасного правового розвитку людської цивілізації на міжнародній арені в умовах глобалізації.

На нашу думку, тендениії щодо формування МПС ТГ через глобалізацію прав людини передбачають суттєві зміни в системі координат відносин між людиною, державою та міжнародним співтовариством держав, що докорінно змінюються в умовах глобалізації.

По-перше, це проявляється в тому, що проблема прав людини в умовах глобалізації є найбільш складною та суперечливою, що з одного боку, - порушує: а) монополію держави на встановлення правового статусу людини на їі території та б) вимоги до меж такого статусу і в) «кадастру» прав людини, що входять до такого статусу, а з іншого - вимагає невідкладних, узгоджених і ефективних заходів, що вживаються не лише на рівні національних держав, але і на всесвітньому рівні (фактор зміни публічно-владних координат відносно ролі людини та ії спільнот у відносинах «держава міжнародне співтовариство». - авт.).

По-друге, треба враховувати, що глобалізація підняла якісно нові системні проблеми, пов'язані із розумінням, здійсненням, розвитком i трансформацією прав людини, прискорила їх універсалізацію, поставила нові завдання перед світовою спільнотою. Так, у своєму виступі на Генеральній Асамблеї Організації Об’єднаних Націй 23 вересня 2003 року Генеральний секретар $\mathrm{OOH}$ Кофі Аннан відзначав, що на глобалізацію необхідно дивитися «очима людей, піднімаючись вище інтересів власних країн і вірно вловлюючи надії і побоювання нашого спільного людського будинку ... Зараз більше людей, ніж будь-коли в минулому, не хочуть запізнитися на потяг глобалізації; але вони хочуть знати, куди він прямує, і бути впевнені, що він рухається з достатньою для виживання швидкістю» ${ }^{1}$ (фактор зміни телеологічно-пізнавальних домінант ролі людини та іiі спільнот у відносинах «держава - міжнародне співтовариство». - авт.).

\footnotetext{
${ }^{1}$ Всемирная комиссия по социальным аспектам глобализации (2004). Справедливая глобализация: создание возможностей для всех, 3. 〈https://www.ilo.org/public/russian/standards/relm/ilc/ilc92/pdf/rep-wc.pdf〉 (2021, липень, 28).
} 
По-третє, треба розуміти, що інститут «глобалізація прав людини» є порівняно новим у національній та міжнародній юриспруденції, і хоча в юридичній літературі про цю категорію пишуть досить часто, однак чіткого визначення його в науці поки ще немає. Найчастіше в літературі він зустрічається у вигляді: «глобалізація в області прав людини», «глобалізація і права людини», «глобалізація в людському вимірі», «глобалізація в соціальному вимірі». Разом 3 тим, вже існують деякі доктринальні підходи до визначення цієї категорії. Так, Л. С. Леонова зазначає, що «оптимальним визначенням глобалізації в області прав людини може бути визнання універсального статусу прав людини, закріплення прав і свобод людини та їх захисту на міжнародному рівні» ${ }^{1}$. Тобто, мова йде про конкретні міжнародно-правові заходи щодо визнання, легалізації, легітимації членами міжнародного співтовариства держав концепту прав людини та створення відповідних міжнародних правозахисних механізмів. Крім того, на діловому порталі - Центр управління фінансами (Centeryf.ru) - без вказівки автора - наводиться матеріал, в якому зазначено, що «глобалізація прав людини відбила тенденцію пов'язаності окремого із загальним - статус і соціальне самопочуття індивіда стали не лише залежати, а й впливати на життя народів і людства загалом, і навпаки» ${ }^{2}$. Наведена позиція досить яскраво підкреслює наші теоретичні положення, по-перше, про набуття ТГ глобалістського потенціалу через формування у неї відповідної МПС, i, по-друге, про виникнення складної і комплексної системи міжнародних відносин, що базується на дихотомії «індивідуального і загального», а також «локального і глобального» (фактор зміни змістовно-аксіологічних наративів відносно ролі людини та ії спільнот у відносинах «держава - міжнародне співтовариство» - авт.).

По-четверте, узагальнюючи ці підходи, можна визначити, що глобалізація прав людини - це процес: а) перманентного впливу різних чинників міжнародного значення (економічних, політичних, культурних та інформаційних) на права людини в окремих державах; б) формування не тільки опосередкованої, а і прямої взаємозалежності соціального стану індивіда від життя народів і людства в цілому, і навпаки; в) це універсалізація позитивного світового досвіду в області прав людини, визнання і закріплення універсального статусу прав і свобод людини, їх захисту на міжнародному рівні (фактор зміни конотативного розуміння ролі людини та її спільнот у відносинах «держава міжнародне співтовариство» - авт.).

Нормативною основою глобалізації прав людини виступають Загальна декларація прав людини 1948 року та два Міжнародних пакти, що уточнюють та забезпечують облігаторно-реалізаційними механізмами іiі настанови, а саме: Міжнародний пакт про економічні, соціальні і культурні права 1966 року та Міжнародний пакт про громадянські і політичні права 1966 року, Свропейська конвенція про захист прав людини і основоположних свобод 1950 року та ін.

На нашу думку, наведені фактори не тільки об'єктивують необхідність формування МПС для ТC, а й підсилюють глобалістський потенціал територіальної людської спільноти, структуруючи та моделюючи його відповідним чином, тобто, в контексті реалізації екзистенційних прав і свобод людини, що в умовах глобалізації сприяє зміцненню іiі ролі у міжнародних інституційних правотворчих та правозахисних процесах.

Тендениії щодо формування МПС ТГ в умовах глобалізачії в сфері формування міжнародних правових стандартів, включаючи відповідні стандарти в сфері прав людини та в сфері МСВ, на нашу думку, базуються на наступних підходах:

По-перше, формування міжнародних правових стандартів в сфері прав людини є одним 3 магістральних завдань сучасного міжнародного права саме в сфері міжнародного захисту прав людини, - тобто, створення норм, що регулюють відносини між державами та іншими суб'єктами міжнародного права, спрямовані на забезпечення гарантованих міжнародними угодами прав і свобод особи (фактор розвитку міжнародного права в сфері захисту прав людини як відображення генеральної тенденції в сфері захисту прав індивіда та його спільнот - авт.).

По-друге, нормативна феноменологія «стандарти прав людини», що в останні роки у міжнародно-правових відносинах набуває все більшої ваги, володіє ідентифікаційними ознаками, бо саме через стандартизацію прав людини, яка є ключовою підставою визнання тієї чи іншої правової системи такою, що відповідає чи не відповідає демократичним прагненням розвитку людства, визначає демократизм та правовий характер конкретної держави (фактор сучасного розвитку

\footnotetext{
1 Леонова, Л. С. (2002). Глобалізація прав людини. Наукові записки. Національний університет "Києво-Могилянська академія", 20, 2, 306.

2 Шаталов, С. К. (2021). Глобализация прав человека в глобальном мире. Центр управления финансами <https://center-yf.ru/data/Yuristu/globalizaciya-prava-cheloveka-v-globalnom-mire.php> (2021, липень, 28).
} 
міжнародного права в сфері захисту прав людини як відображення його фрагментації в сфері захисту прав індивіда та його спільнот - авт.).

По-третє, в загальному уявленні, стандартизація прав людини спрямована, насамперед, на забезпечення мінімальних правових засобів захисту людини тією мірою, в якій це дає їй змогу реалізовувати особистий потенціал в різних сферах (фактор розвитку міжнародного права в сфері захисту прав людини як відображення стійкої тенденції встановлення мінімальних вимог для держав в сфері захисту прав індивіда та його спільнот - авт.).

По-четверте, стандартизація прав людини є необхідним процесом хоча б $з$ позицій визнання гідності кожної людини, незалежно від ії громадянства, релігійної, національної, статевої, мовної та інших ознак та закріплення імперативного принципу рівності людини в національному конституційному законодавстві держави (фактор розвитку міжнародного права в сфері захисту прав людини як мета щодо закріплення принципу рівності людини в національному праві в сфері захисту прав індивіда та його спільнот - авт.).

По-п'яте, у сфері міжнародного захисту прав людини міжнародні стандарти відіграють величезну роль, зважаючи на те, що виконання зобов'язань щодо заохочення загальної поваги, дотримання і захисту прав людини і основних свобод $є$ обов'язком усіх держав-членів ООН (фактор розвитку міжнародного права в сфері захисту прав людини через закріплення міжнародно-правових зобов'язань держави в сфері захисту прав індивіда та його спільнот - авт.).

По-шосте, феноменологія «міжнародний стандарт» в теорії міжнародного права зустрічається часто, воно стосується різних сфер міждержавних відносин, тому визначення стандарту має різні етимологічно-смислові відтінки - даним терміном в досліджуваній сфері позначають як загальні конвенційні положення, так i правила поведінки, закріплені в технічних (технологічнопроцесуальних) документах (фактор розвитку міжнародного права в сфері захисту прав людини через закріплення широкого кола семантико-визначальних якостей його міжнародних і національних джерел в сфері нормативно-процесуального захисту прав індивіда та його спільнот - авт.).

По-сьоме, порівняльний аналіз різних наукових підходів 3 питань стандартизації дозволив визначити диференційований підхід до з'ясування правової природи міжнародних стандартів в різних сферах суспільних відносин. Даний факт формує теоретичну основу для подальшого вивчення всього різноманіття прояву міжнародних стандартів в різних галузях міжнародного права, але, насамперед, в міжнародному праві прав людини, для якого наведена стандартизація має визначально-облігаторне та процесуально-реалізаційне значення (фактор розвитку міжнародного права в сфері захисту прав людини як відображення системи міжнародних зобов'язань держави та формування нею ї обов'язкового виконання через національне конституційне право в сфері захисту прав індивіда та його спільнот - авт.).

По-восьме, структура міжнародних стандартів у сфері прав людини, що на думку окремих авторів, складається із сукупності принципів і норм, що встановлюють: права та свободи людини в різноманітних сферах життєдіяльності; обов'язки держави із забезпечення та дотримання прав людини без будь-якої дискримінації як у мирний час, так і у період збройних конфліктів; загальні принципи природного права; відповідальність за злочинне порушення прав людини; напрями розвитку та розширення сфери прав людини; напрями посилення контрольного механізму за виконанням державами взятих на себе зобов'язань у сфері прав людини ${ }^{1}$, напряму торкаються життєдіяльності людини в межах та ускладі ТГ, що робить наведені стандарти прямим відображенням локального життя людини в специфічній людській спільноті в умовах МСВ в ординарному стані повсякденності (фактор розвитку міжнародного права в сфері захисту прав людини як відображення тенденцій ії повсякденного життя в ТГ на локальному рівні соціуму в умовах МСВ - авт.).

По-дев'яте, на основі цих стандартів кожна держава зобов'язана упорядкувати чинне конституційне законодавство, усунути його протиріччя з нормами міжнародного права, відмінити застарілі норми, ліквідувати прогалини ${ }^{2}$ (фактор розвитку національного конституційного права в сфері захисту прав людини як відображення обов’язкового виконання державою своїх міжнародних зобов'язань - авт.).

По-десяте, звернення держави та міжнародного співтовариства держав до стандартизації норм на міжнародному рівні є обов'язковим елементом та якісною рисою універсалістської концепції прав

\footnotetext{
1 Ліннік, Н. В. (2012). Ціннісне та нормативне у розумінні прав людини. Держсава і право, 56, 46.

2 Зайчук, О. В., Оніщенко, Н. М. (ред.) (2008). Теорія держави і права. Київ: Юрінком Інтер, 105.
} 
людини, яка базується, передусім, на здобутках міжнародного права. Водночас, існування регіональних стандартів прав людини, як це не дивно, жодним чином не спростовують універсалізму нормативності прав людини, а лише доповнюють цю систему знань (фактор розвитку міжнародного права в сфері захисту прав людини як відображення тенденцій універсалізації концепту прав людини - авт.).

По-одинадцяте, сучасне міжнародне право прагне до конкретизації загальнолюдських стандартів прав і свобод особистості, з якими держави повинні узгоджувати внутрішне законодавство та поводження посадових осіб з громадянами, - а це ще раз підкреслює первинний характер типізованих та стереотипних форм життєдіяльності людини в межах ТГ в умовах МСВ, що запозичуються міжнародним правом для процесів міжнародної нормативізації та легалізації прав людини (фактор розвитку міжнародного права в сфері захисту прав людини як відображення запозичення ним тенденцій іiі соціалізації та набуття габітусів в повсякденному житті в ТГ в умовах МСВ - авт.).

По-дванадцяте, інтеграція України усвітове співтовариство неможлива без приведення у відповідність з міжнародними стандартами прав людини національного конституційного законодавства, а потім і відповідного галузевого законодавства, а також і правозастосовної діяльності (фактор розвитку міжнародного права в сфері захисту прав людини як відображення об'єктивної тенденцій оновлення законодавчого масиву держави - авт.).

Нормативною основою міжнародних правових стандартів МСВ виступають Свропейська хартія місцевого самоврядування 1985 року, Свропейська рамкова конвенція про транскордонне співробітництво між територіальними общинами або властями 1980 року, Свропейська хартія про участь молоді в муніципальному та регіональному житті 1992 року (Переглянута Свропейська хартія про участь молоді в місцевому та регіональному житті 2003 року), Конвенція про участь іноземців у суспільному житті на місцевому рівні 1992 року, Свропейська ландшафтна конвенція 2000 року, проект Всесвітньої Хартії місцевого самоврядування ООН та ін.

На нашу думку, наведені фактори не тільки об'єктивують необхідність формування міжнародних правових стандартів для МСВ та ТС, вони також: а) демонструють відповідні складнощі їх сприйняття конституційними правопорядками держав-членів міжнародної та регіональних спільнот; б) виступають свідченням наявності єдиної міжнародно-правової та нормативно-діяльнісної позиції держав-членів (учасників) міжнародних багатосторонніх міждержавних договорів відносно МПС ТГ; в) об'єктивно підсилюють глобалістський потенціал ТГ через можливість встановлення їх міжнародної комунікації з аналогічними спільнотами, іншими суб'єктами інших держав, а також з іншими учасниками системи міжнародних відносин, включаючи міжнародні неурядові організації місцевих влад.

Тендениії щцодо формування МПС ТГ в умовах глобалізації в сфері формування та реалізаиії методологічних та технологічних настанов глобального конституиіоналізму детерміновані наступним:

По-перше, треба враховувати, що сформована термінологічна система «глобальний конституціоналізм» у вигляді соціального концепту інтегративним шляхом об'єднує в своєму змісті три основоположні поняття - глобалізація, конституціоналізм, глобальний конституціоналізм. Опорним терміном в цій терміносистемі виступає конституціоналізм, що функціонує в умовах глобалізації. Звідси, інститут МСВ як інститут національного конституціоналізму обгрунтовано і закономірно виступає як об'єкт конституціоналізму глобального, коли МСВ як об'єкт абсолютно-пріоритетного національного конституційно-правового регулювання трансформується у об'єкт міжнародноправового регулювання і в умовах правової глобалізації набуває глобального значення та вимірювання. МCB як природна форма існування і функціонування ТГ - первинного соціально-колективного конструкту і осередку життєдіяльності і одночасно охорони і захисту людської цивілізації, що уособлюється конкретною людиною, ії групами і асоціаціями, - починає оцінюватись: а) з позицій його глобального значення; б) в контекстуалізації його якісно-процесуального вимірювання та в) поведінково-діяльнісного продовження його планетарного розвитку і г) в розумінні становлення системи глобальної комунікативної взаємодії людей (фактор обгрунтованої появи ТГ в якості суб'єктаоб’єкта глобального конституціоналізму, що актуалізує питання формування ії МПС - авт.).

По-друге, треба звернути увагу на революційний характер глобалізації, яка на думку, К. Аннана, колишнього Генерального секретаря ООН, свідчить про те, що вона докорінно перебудувала сучасну людську епоху, причому «не тільки способи освоєння світу, а й способи нашого 
спілкування один 3 одним» ${ }^{1}$. Транспонування наведеної доктринальної позиції на розуміння конституціоналізму, як політико-правової системи суспільства, історію, теорія та практику конституційного будівництва ${ }^{2}$, в розумінні формування глобального конституціоналізму дає нам факт запозичення національних конституційних цінностей на глобальний рівень та їх застосування через призму принципів, норм і механізмів міжнародного публічного права, в основі яких лежить комунікативна взаємодія держав міжнародного співтовариства та відповідний перелік форм їх взаємодії у вигляді міжнародного співробітництва. Отже, такий процес дає змогу інституту МСВ та ТГ, що його уособлюють, безпосередньо приймати участь у процесах глобальної взаємодії суб'єктів міжнародного права і акторів міжнародних відносин, просуваючи свої інтереси та відстоюючи свої позиції у глобальному порядку денному з обгрунтованими запитами та претензіями на їх легалізацію на глобальному рівні в межах міжнародного співтовариства держав, але все ж з їх локальнорегіональною інтерпретацією відносно можливості застосування і реалізації (фактор формування порядку денного глобальної взаємодії в межах міжнародного співтовариства з урахуванням інтересів та питань локально-регіонального розвитку МСВ та ТГ в контексті їх легалізації, що детермінує процеси формування МПС ТГ - авт.).

По-третє, розглядаючи конституціоналізм у його змістовному розумінні, автори-укладачі «Енциклопедчиного словника конституційного права» зазначають, що конституціоналізм - «складна суспільно-політична і державно-правова категорія, основу якої складають ідеали конституційної демократії (тобто демократії, що базується на наявності конституції як особливому документі держави і суспільства), наявність певних інститутів влади, відповідного конституції політичного режиму і система захисту цінностей демократії, прав і свобод людини і громадянина, конституційного ладу в цілому» ${ }^{3}$ «Юридичний словник» трактує конституціоналізм як «теорію і практику організації державного і суспільного життя відповідно до констутуції» ${ }^{4}$. Автори-упорядники «Соціологічного словника» визначають конституціоналізм як «тип управління державою, який здійснюється на основі закону, конституції, що характеризується наявністю: вищого законодавчого органу, що обирається населенням; відповідальності уряду перед законодавчим органом або главою держави; загального виборчого права; інституту демократичних прав і свобод, правосуддя» 5 .

Отже, наведені підходи, що тлумачать в семантичному розумінні дефінітивні визначення поняття конституціоналізм, свідчать про різноманіття їх підходів: як системи управління державою, заснованої на конституційних засадах; як складної суспільно-політичної та державно-правової категорії, заснованої на ідеалах конституційної демократії; як форми правління, заснованої на конституційно визначених принципах; як теорії і практики організації державного і суспільного життя відповідно до конституції. Однак, треба розуміти, що в основі конституційних засад, конституційної демократії, конституційних принципів, організації державного і суспільного життя відповідно до конституції лежить основоположний концепт «права людини», що виступає «альфою і омегою» конституційної державності, отже, права людини, iї груп і асоціацій в межах ТГ та в умовах МСВ як основної, єдиної, оптимальної форми існування людської цивілізації актуалізують проблематику формування МПС ТГ (фактор обгрунтованої появи МПС у МСВ та ТГ в рамках конституціоналізму, враховуючи, що в його основі лежить концепт «права людини» - авт.).

По-четверте, торкаючись дефінітивного визначення глобального конституціоналізму, запропонованого представниками конституційно-правової доктрини ${ }^{6}$, треба розуміти його як: a) соціальну концепцію, що б) являє собою систему знань політико-правового характеру, в) засновану на фундаментальних демократичних цінностях щодо необхідності організації міждержавного, державного і суспільного життя в загальнопланетарному масштабі відповідно до ідеологічної основи

\footnotetext{
${ }^{1}$ Аннан, К. (1998). Обновление ООН: программа реформ. Международная жизнь, 4, 24.

${ }^{2}$ Орзіх, М. П. (2015). Конституціоналістика у складі юридичних терміно-понять. Избранные труды: юбилейное издание к 90-летию со дня рождения. Одесса: Юридична література, 311.

${ }^{3}$ Enc-Dic (2021). Эничклопедический словарь конституциионого права <http://enc-dic.com/print/constitution/Konstitucionalizm-768.html> (2021, липень, 28).

${ }^{4}$ Enc-Dic (2021). Юридический словарь <http://enc-dic.com/print/legal/ Konstitucionalizm-7707.html> (2021, липень, 28).

${ }^{5}$ Enc-Dic (2021). Социологический словарь <http://enc-dic.com/sociology/ Konstitucionalizm-3162.html> (2021, липень, 28).

${ }^{6}$ Гончаров, В. В. (2017). Проблемы содержания и типологии глобального конституционализма как социальной концепции. Studia Politologiczne, 44 <https://cyberleninka.ru/article/n/problemy-soderzhaniya-i-tipologii-globalnogokonstitutsionalizma-kak-sotsialnoy-kontseptsii > (2021, липень, 28).
} 
сучасного етапу розвитку капіталізму в світі, яка г) обгрунтовує мінімізацію негативних наслідків у розвитку капіталістичної системи шляхом експорту витрат від центру (ядра) до ії периферії, г) спирається на єдину систему поділу праці в рамках світового ринку, д) спрямована на забезпечення розвитку світового капіталістичного фінансово-економічного базису і його суспільно-політичної надбудови, е) здійснюється шляхом військово-політичної, фінансово-економічної, культурно-творчої та інформаційної експансії Заходу в загальнопланетарному масштабі за є) допомогою нав'язування сформованих єдиних керуючих центрів регулювання і контролю національним державам західних державно-правових, суспільно-політичних інститутів, принципів, зав'язків, відносин, ідей з метою захисту і просування фінансово-економічних інтересів і потреб.

Отже, системний підхід до розуміння наведеної позиції, що характеризується відповідним негативним відношенням до західних цінностей, дає змогу констатувати наявність відповідної системи пріоритетів глобального конституціоналізму, що суттєво впливає на появу досліджуваної нами МПС МСВ та ТГ, що лежить в основі формування глобалістського потенціалу територіальної людської спільноти. До таких пріоритетів відносяться наступні: а) фундаментальні демократичні цінності щодо об'єктивної необхідності організащії міждержсавного, державного і суспільного життя в загальнопланетарному масштабі відповідно до ідеологічної основи сучасного етапу розвитку капіталізму в світі (враховуючи глобальний характер розвитку таких відносин можна говорити про розвиток соціально-демократичної державності - авт.); б) формування економічного базису глобального конституціоналізму, що спирається на єдину систему поділу пращі в рамках світового ринку; в) здійснення завдань глобального конституціоналізму через забезпечення розвитку світового капіталістичного (соціал-демократичного - авт.) фінансово-економічного базису і його суспільно-політичної надбудови; г) формування засад такого конституціоналізму шляхом відповідної експансї̈ західних иінностей, зокрема в фінансово-економічній, культурно-творчій та інформачійній сферах в загальнопланетарному масштабі; г) формування управлінської системи такої форми конституціоналізму за допомогою діяльності сформованих єдиних керуючих центрів регулювання $i$ контролю для національних держав; д) формування інституційно-нормативних засад такої форми конституціоналізму через сприйняття державами західних державно-правових, суспільно-політичних інститутів, принципів, зав 'язків, відносин, ідей з метою захисту і просування фінансово-економічних інтересів $i$ потреб; е) вважаємо необхідним додати до розуміння концепції глобального конституціоналізму наявність загальнолюдських проблем глобального характеру, що вдало «вписуються» в аргументацію щодо надання МСВ, ТГ феноменологічної ознаки МПС, - до останніх, наприклад, можна віднести екологічні питання існування людської цивілізації, вирішення яких в останні роки не тільки активізувалось, а й суттєво загострилось.

Наведені нами фактори мають не лише глобальне і загальнодержавне значення - вони, по-перше, i, насамперед, формуються, виникають, проявляються, реалізуються, вдосконалюються і трансформуються на локальному рівні соціуму в царині існування і функціонування ТГ в умовах $\mathrm{MCB}$; по-друге, вони торкаються глибинних засад існування людини в сучасному світі. Отже, маємо наскрізні вертикально-горизонтально управлінсько-економічні, управлінсько-політичні, управлінсько-культурологічні, управлінсько-соціальні зв'язки, парадигмальні управлінські ланцюжки, системні різнорівневі управлінські комплекси, що володіють інституційною та нормативною базою для свого існування і реалізації на локальному рівні соціуму, через усвідомлення наведених процесів та їх вплив на свідомість конкретної людини через концепт пї прав і свобод (фактор обгрунтованої появи МПС у МСВ та ТГ в рамках глобального конституціоналізму, враховуючи, що в його основі та на всіх рівнях його прояву лежить концепт «права людини» - авт.).

Вважаємо, що усвідомлення і реалізація наведених тенденцій в сфері формування МПС ТГ в умовах глобалізації за вказаними трьома напрямками: в сфері глобалізації прав людини; в сфері формування міжнародних правових стандартів, включаючи відповідні стандарти в сфері прав людини та в сфері МСВ; в сфері формування та реалізації методологічних та технологічних настанов глобального конституціоналізму - буде, по-перше, сприяти виконанню цього стратегічного доктринально-теоретичного i одночасно праксеологічно-функціонального характеру; по-друге, активізувати процеси становлення, формування і посилення глобалістського потенціалу ТT.

Висновки. Проведене дослідження дає змогу зробити наступні висновки:

- концепт «права людини» відіграє стратегічну роль у формуванні міжнародної правосуб'єктності територіальної людської спільноти в умовах глобалізації, що напряму сприяє формуванню глобалістського потенціалу територіальних громад; 
- застосування концепту «права людини» упроцесах формування міжнародної правосуб'єктності територіальної людської спільноти в умовах глобалізації має не стільки ідеологічне, скільки суто практичне значення, бо сприяє усвідомленню світовим співтовариством держав ролі і значення територіальної громади в процесах: а) здійснення життєвого циклу людини в громаді; б) реалізації ii репродуктивної функції; в) продовження іiї роду; г) подальшого розвитку людської цивілізації;

- розуміння та усвідомлення наведених процесів вже під кутом зору глобалізації, може бути охарактеризовано як вирішення задач глобального розвитку людської цивілізації та виконання природного призначення людини, що може бути визначено за допомогою «наскрізного» розуміння локального, загальнодержавного, універсально-глобального рівнів соціуму у їх функціональнологічній взаємодії та відповідної управлінської та нормативної (локальне, загальнодержавне, міжнародно-правове нормопроєктування та нормотворчість /у підсумку, нормотворення/) діяльності, що пояснює, обгрунтовує, детермінує, активізує, актуалізує та стимулює появу такої взаємодії;

- розуміння ролі і значення концепту «права людини» у формуванні міжнародної правосуб’єктності територіальної людської спільноти в умовах глобалізації має значення в контексті формування не лише політичних смислів, а й відповідних дій-функцій окремих держав, їх міжнародного співтовариства у формуванні парадигми дій, включаючи нормопроєктування та нормотворчість різного рівнів (локальну, загальнодержавну, міжнародно-правову) щодо формування відповідної організаційної, організаційно-правової засад щодо процесів формування МПС і особливо нормативної складової МПС МСВ та ТГ;

- усвідомлення і реалізація тенденцій у сфері формування МПС ТГ в умовах глобалізації за вказаними автором трьома напрямками: в сфері глобалізації прав людини; в сфері формування міжнародних правових стандартів, включаючи відповідні стандарти в сфері прав людини та в сфері MCB; в сфері формування та реалізації методологічних та технологічних настанов глобального конституціоналізму, буде не лише сприяти виконанню цього завдання стратегічного доктринальнотеоретичного і одночасно праксеологічно-функціонального характеру, а й активізувати процеси становлення, формування і посилення глобалістського потенціалу ТГ.

\section{References:}

1. Konstytutsiya Ukrayiny, 1996 (Verkhovna Rada Ukrayiny) [Constitution of Ukraine, 1996 (Verkhovna Rada of Ukraine)]. Vidomosti Verkhovnoyi Rady Ukrayiny [Information of the Verkhovna Rada of Ukraine], 30, 141. [in Ukrainian].

2. Wikipedia (2021). Prava lyudyny [Human Rights] 〈https://uk.wikipedia.org/wiki/Права_людини〉 (2021, July, 28). [in Ukrainian].

3. Tertyshnyk, V. M. (2009). Verkhovenstvo prava ta zabezpechennya vstanovlennya istyny v kryminalnomu protsesi Ukrayiny [Rule of law and ensuring the establishment of truth in the criminal process of Ukraine]. Dnipropetrovsk: DDUVS; Lira LTD. [in Ukrainian].

4. Korelskiy, V. M., Perevalova, V. D. (2002). Teoriya gosudarstva i prava [Theory of Government and Rights]. Moscow: NORMA. [in Russian].

5. Pushkina, O. V. (2006). Systema prav i svobod lyudyny ta hromadyanyna v Ukrayini: teoretychni i praktychni aspekty zabezpechennya [The system of human and civil rights and freedoms in Ukraine: theoretical and practical aspects of security]. Kyiv: Logos. [in Ukrainian].

6. Zaychuk, O. V., Onishchenko, N. M. (ed.) (2008). Teoriya derzhavy i prava [Theory of state and law]. Kyiv: Yurinkom Inter. [in Ukrainian].

7. Onishchenko, N. M., Zaychuk, O. V. (ed.) (2007). Problemy realizatsiyi prav i svobod lyudyny ta hromadyanyna $v$ Ukrayini [Problems of realization of human and civil rights and freedoms in Ukraine]. Kyiv: Yurydychna dumka. [in Ukrainian].

8. Vsemirnaya komissiya po sotsialnym aspektam globalizatsii [World Commission on the Social Dimension of Globalization ] (2004). Spravedlivaya globalizatsiya: sozdaniye vozmozhnostey dlya vsekh [A Fair Globalization: Creating Opportunities for All] <https://www.ilo.org/public/russian/standards/relm/ilc/ilc92/pdf/rep-wc.pdf> (2021, July, 28). [in Russian].

9. Leonova, L. S. (2002). Hlobalizatsiya prav lyudyny [Globalization of human rights]. Naukovi zapysky. Natsionalnyy universytet Kyevo-Mohylyanska akademiya [Proceedings. National University of Kyiv-Mohyla Academy], 20, 2, 306-308. [in Ukrainian].

10. Shatalov, S. K. (2021). Globalizatsiya prav cheloveka v globalnom mire [Globalization of human rights in the global world]. Tsentr upravleniya finansami [Financial Management Center] $<$ https://center-yf.ru/data/Yuristu/globalizaciya-prava-cheloveka-v-globalnom-mire.php> (2021, July, 28). [in Russian]. 
11. Linnik, N. V. (2012). Tsinnisne ta normatyvne u rozuminni prav lyudyny [Value and normative in the understanding of human rights]. Derzhava i pravo [State and law], 56, 43-47. [in Ukrainian].

12. Annan, K. (1998). Obnovleniye OON: programma reform [Renewal of the UN: a reform agenda]. Mezhdunarodnaya zhizn [International life], 4, 24-32. [in Russian].

13. Orzikh, M. P. (2015). Konstitutsionalistika u skladi yuridichnikh termino-ponyat. Izbrannyye trudy: yubileynoye izdaniye $\mathrm{k}$ 90-letiyu so dnya rozhdeniya [Constitutionalistics at the warehouses of legal terms and understand. Selected Works: Jubilee Edition for the 90th Birthday Anniversary]. Odessa: Legal Literature. [in Ukrainian].

14. Enc-Dic (2021). Entsiklopedicheskiy slovar konstitutsionnogo prava [Encyclopedic Dictionary of Constitutional Law] <http://enc-dic.com/print/constitution/Konstitucionalizm-768.html> (2021, July, 28). [in Russian].

15. Enc-Dic (2021). Yuridicheskiy slovar [Legal Dictionary] 〈http://enc-dic.com/print/legal/ Konstitucionalizm-7707.html〉 (2021, July, 28). [in Russian].

16. Enc-Dic (2021). Sotsiologicheskiy slovar [Sociological Dictionary] <http://enc-dic.com/sociology/ Konstitucionalizm-3162.html> (2021, July, 28). [in Russian].

17. Goncharov, V. V. (2017). Problemy soderzhaniya i tipologii globalnogo konstitutsionalizma kak sotsialnoy kontseptsii [Problems of the content and typology of global constitutionalism as a social concept]. Studia Politologiczne, 44 <https://cyberleninka.ru/article/n/problemy-soderzhaniya-i-tipologii-globalnogokonstitutsionalizma-kak-sotsialnoy-kontseptsii > (2021, July, 28). [in Russian]. 